\title{
Estrogenic Effect of the Leaves from Katuk (Sauropus androgynus L. Merr) on Vaginal and Endometrial Atrophy in Perimenopausal Mice
}

\author{
Retno Susilowati*, Lailatul Khoiriyah, Exma Mutatal Hikmah
}

Retno Susilowati*, Lailatul Khoiriyah, Exma Mutatal Hikmah

Department of Biology, Faculty of Science and Technology, State Islamic University of Maulana Malik Ibrahim Malang, Malang 65144, East Java, INDONESIA.

\section{Correspondence}

\section{Retno Susilowat}

Department of Biology, Faculty of Science and Technology, State Islamic University

of Maulana Malik Ibrahim Malang, Malang

65144, East Java, INDONESIA.

Phone no: +62 813-3460-0071

Fax: +62 $341-558933$

E-mail: retno.susilowati@bio.uin-malang.ac.id

History

- Submission Date: 16-11-2019;

- Review completed: 18-12-2019;

- Accepted Date: 03-01-2020.

DOI : 10.5530/pj.2020.12.37

Article Available online

http://www.phcogj.com/v12/i2

Copyright

(C) 2020 Phcogj.Com. This is an openaccess article distributed under the terms of the Creative Commons Attribution 4.0 International license.

\begin{abstract}
Objective: To examine the potency of estrogenic effect of Katuk (or star gooseberry or sweet leaf) Sauropus androgynus L. Merr (Phyllanthaceae) leaf extract on the vaginal and endometrial atrophy in perimenopausal mice model.

Methods: Completely random experiments divided into 4 groups with 5 female mice in each group: control group (N), perimenopause group which induced by 4-vynil cyclohexene dioxide (VCD) (P0), perimenopause group followed by $S$. androgynus leaves extract administration with 15 and $30 \mathrm{mg} / \mathrm{kg} \mathrm{BW}$ (P15 and P30). The mice were induced to artificial perimenopause with $160 \mathrm{mg} / \mathrm{kg}$ body weight (BW) of VCD 5 times/week for 2 weeks and continuously treated with S. androgynus leaf extract for 30 days. Vaginal smear examination, maturation index (MI), vaginal epithelium and endometrial thickness were observed. Data were analyzed using a standard one-way ANOVA with LSD Test by SPSS 16.0 for Windows.

Results: Administration of $S$. androgynus leaf extract for 30 days to perimenopausal mice model significantly decreased the duration of mice diestrus phase $(p<0.01)$ compared to perimenopause mice. S. androgynus leaf extract treatment at dose $30 \mathrm{mg} / \mathrm{kg} \mathrm{BW}$ led to higher vaginal epithelium thickness and maturation index compared to another group $(p<0.01)$. The effective dose to enhance the vaginal epithelial and endometrial cells proliferation was $30 \mathrm{mg} /$ $\mathrm{kg} \mathrm{BW}$.

Conclusions: $S$. androgynus leaf extract had a good estrogenic action that it might be useful for therapy of vaginal and endometrial atrophy caused by perimenopause effect.

Key words: Laboratory mice; Perimenopause; S. androgynus leaf extract; Estrogenic effect; Vaginal atrophy; Endometrial atrophy.
\end{abstract}

\section{INTRODUCTION}

Basically, the main purpose of treating vaginal atrophy is to decrease symptoms. ${ }^{1}$ There are some therapies available to decrease symptoms of vaginal atrophy including hormone therapy, vaginal lubricant and vaginal estrogen. ${ }^{2}$ Food and Drug Administration (FDA) recommend estrogen treatment to cure vaginal atrophy. ${ }^{3}$ Estrogen therapy given orally or vaginally was known successfully reduces the symptoms of vaginal atrophy like dryness, sexual dysfunction and vaginal atrophy. ${ }^{4}$ Nevertheless, the long term effect of use estrogen may risk breast cancer, endometrial cancer and coronary heart disease. ${ }^{3}$

Phytoestrogen is an alternative treatment to reduce the side effect of perimenopause. ${ }^{1,5}$ Phytoestrogen, also called dietary estrogens, are plant-derived xenoestrogen that similar with $17 \beta$ estradiol (E2). ${ }^{6}$ Many plant were reported containing phytoestrogen such as soybean, ${ }^{1}$ Pomegranate, ${ }^{5}$ Fennel $^{3}$ and Katuk. ${ }^{7}$ Katuk, or star gooseberry or sweet leaf Sauropus androgynus L. Merr (Phyllanthaceae) was native Indonesian plant that has been used by local people to treat reproductive problems. ${ }^{8}$ Katuk contains active compounds androstan-17-one and 3-ethyl-3-hydroxy-5-alpha which serves as a precursor or intermediate-step in synthesis of steroid hormone (progesteron, estrogen, testosteron and glucocorticoid). Furthermore, S. androgynus contains isoflavones that categorized as phytoestrogen and it had been used for treating vaginal atrophy. ${ }^{1}$ In addition to affecting the anatomy of the vagina, a decrease in estrogen levels or estrogenic activity will also cause endometrial atrophy. Post menopause has a lot of endometrial atrophy and bleeding. ${ }^{9}$

The vaginal epithelial vagina and endometrial tissue have the same estrogen receptor, so it is thought that both give the same response to estrogen or phytoestrogens effect in the proliferative response. There are no studies yet regarding the effectiveness of $S$. androgynus to treat vaginal and endometrial atrophy as an alternative therapy for decreasing the sympton of vaginal and endometrial atrophy. The current study aimed to examine the potency of estrogenic effect of $S$. androgynus leaf extract on vaginal epithelium and endometrium atrophy in perimenopausal mice model. Maturation index (MI) is a ratio of parabasal cells, intermediate cells and superficial cells and can be used to evaluate estrogen activity. The parameter used to detect vaginal and endometrial atrophy were the thickness of vaginal ephitelial and endometrial layer. 


\section{MATERIALS AND METHODS}

\section{Animals and treatment}

Total of 20 female mice Balb/c, (28 days old) were acclimatized for 7 days and maintained on photoperiod treatment 12 hours in dark and light cycles at $22 \pm 2^{\circ} \mathrm{C}$. During the acclimatization process, mice were fed with standard chow and adlibitum water. After acclimatization period, all mice with weight 21-25 g were selected for subsequent treatment.

All selected mice were divided into 4 groups: control group $(\mathrm{N})$, perimenopausal mice group (P0), perimenopausal mice treated with S. androgynus leaf extract at dose of 15 and $30 \mathrm{mg} / \mathrm{kg}$ BW. Estrous synchronization was done by prostaglandin intramuscular injection dose of $13.2 \mathrm{mg} / \mathrm{kg}$ BW before VCD injection. All groups of treatment mice were injected with $160 \mathrm{mg} / \mathrm{kg}$ BW of VCD 5 times/week for 2 weeks to induce artificial perimenopause. ${ }^{10}$ All mice of treatment group were treated with S. androgynus leaves extract for 30 days.

\section{Duration of diestrus phase}

Diestrus phase periodically observed three times a day for 7 days at the end of VCD injection and herbal treatment using vaginal smear method. Samples of the vaginal epithelium were obtained by sucking with $\mathrm{NaCl}$ solution $0.9 \%$. $\mathrm{NaCl}$ solution in pipette was inserted into vaginal wall and sucking back quickly. Smear were applied to a slide glass and stained by the Giemsa staining for diestrus phase examination. Diestrus phase shown by leucocyte domination. ${ }^{11}$

\section{Estrogenic effect}

Maturation index (MI) was measured with following Equation 1:

$\mathrm{MI}=0.5 \times \sum$ intermediate cells $+\sum$ superficial cells

The qualitative assessment of estrogenic effect was performed. Maturation index (MI) between 0-49 were classified as a low level of estrogen effect, maturation index between 50-64 were classified as a moderate level of estrogenic effect whereas maturation index 65-100 were classified as high level of estrogenic effect.

\section{Vaginal and endometrial atrophy}

Vaginal and uterine samples were isolated on diestrus phase then vagina and endometrium histology were made by using HE staining with the thickness about $6 \mu \mathrm{m}$. Vaginal and endometrial thickness measurements carried out by Pro-Express image software. For histological examination, specimen was stained using the hematoxylin and eosin (H\&E) procedure. Specimens were observed under CX31 Olympus microscope.

\section{Statistical analysis}

All statistics and analysis were performed using SPSS 16.0 for Windows. One Way ANOVA test was used to assess the statistical difference between the treatment groups. Different between each treatment was analyzed with Least Significant Difference (LSD) test.

\section{RESULTS}

\section{Duration of diestrus phase}

In this study, VCD induction of perimenopause in mice was significantly increased the duration of mice diestrus phase $(\mathrm{p}<0.01)$. Treatment with $S$. andogynus extract was significantly decreased the duration of diestrus phase $(\mathrm{p}<0.01)$. P15 and P30 group ameliorated the duration of diestrus phase to normal condition. Duration phase in P15, P30 and normal group were $91.2 \pm 12.13 \mathrm{~h}, 78 \pm 6.69 \mathrm{~h}$ and $80.0 \pm 8.0 \mathrm{~h}$, respectively (Table 1 ). Meanwhile, the duration of diestrus phase in P0 group was $140.8 \pm 4.38 \mathrm{~h}$. The observation of estrus cycle by vaginal smear examination found that $\mathrm{P} 15$ and P30 group exhibited the recovery folliculogenesis in mice which characterized by proestrus, estrus, and metestrus phase (Figure 1).

\section{Maturation index (MI)}

Maturation vaginal index was measured based on the number of vaginal epithelial cells in each sample. This study proved that administration of $S$. androgynus leaf extract was significantly increased the estrogenic effect as the amount of dose $(\mathrm{p}<0.01)$. Based on vaginal epithelial maturation index, the perimenopause mice vagina indicated the low estrogenic effect. Administration of S. androgynus leaf extract at dose $15 \mathrm{mg} / \mathrm{kg}$ BW increased the estrogenic effect to normal (medium condition) and the high estrogenic effect caused by S. androgynus treatment was found at dose of $30 \mathrm{mg} / \mathrm{kg} \mathrm{BW}$ (Table 2, Figure 2).

\section{Vaginal epithelium and endometrium atrophy}

Administration of $S$. androgynus leaf extract treatment was significantly increased the vaginal epithelium and endometrial thickness at dose dependent manner. However, P30 group (30 mg/kg BW) has not reached the normal thickness on vaginal epithelium thickness (Table 2, Figure 2), but reached the normal thickness on endometrial thickness (Table 3, Figure 3). This study also found that endometrial thickness in perimenopause mice group treated with $S$. androgynus leaf extract (P15 and P30 groups) were higher than P0 group. P30 group were not significantly different $(\mathrm{p}<0.01)$ with negative control group (normal).

Table 1: Diestrus phase length in premenopausal female mice before and after treatment of $S$. androgynus leaf water extract.

\begin{tabular}{ccc}
\hline \multirow{2}{*}{ Group treatment } & \multicolumn{2}{c}{ Mean of diestrus phase (hour) } \\
\cline { 2 - 3 } & Before & After \\
\hline N & $110.4 \pm 8.76^{\mathrm{a}}$ & $80 \pm 8^{\mathrm{a}}$ \\
P0 & $134.4 \pm 8.76^{\mathrm{b}}$ & $140.8 \pm 4.38^{\mathrm{b}}$ \\
P15 & $134.4 \pm 13.14^{\mathrm{b}}$ & $91.2 \pm 12.13^{\mathrm{a}}$ \\
P30 & $125.6 \pm 10.43^{\mathrm{b}}$ & $78.4 \pm 6.69^{\mathrm{a}}$ \\
\hline
\end{tabular}

Note: Different superscript letters in the same column state that there are very significant differences $(\mathrm{p}<0.01)$ between treatment groups.



Figure 1: Vaginal smear examination showed estrous cycle phases with 100x magnification. Note: 1 . Leukocyte; 2 . Cornification cells; 3 . Nucleated epithelial cells. 
Table 2: The number of cells and vaginal epithelial cells thickness, maturation index, and estrogenic effect after S. androgynus leaf extract treatment at various doses in vaginal epithelial of premenopause mice.

\begin{tabular}{|c|c|c|c|c|c|c|}
\hline Group & $\begin{array}{c}\text { Average of Parabasal } \\
\text { cells (\%) }\end{array}$ & $\begin{array}{c}\text { Average of Intermediet } \\
\text { Cells (\%) }\end{array}$ & $\begin{array}{c}\text { Average of superfisial } \\
\text { cells }(\%)\end{array}$ & $\begin{array}{l}\text { Maturation } \\
\text { index }\end{array}$ & Estrogenic effect & $\begin{array}{l}\text { Vaginal epithelium thickness } \\
(\mu \mathrm{m})\end{array}$ \\
\hline $\mathrm{N}$ & 38.15 & 24.57 & 37.28 & $58.5 \pm 2.99^{\mathrm{b}}$ & Medium & $15.75 \pm 0.80^{\mathrm{d}}$ \\
\hline $\mathrm{P} 0$ & 41.84 & 25.51 & 32.65 & $44.5 \pm 2.98^{\mathrm{a}}$ & Low & $8.85 \pm 1.32^{\mathrm{a}}$ \\
\hline $\mathrm{P} 15$ & 26.78 & 33.03 & 40.17 & $63.5 \pm 2.55^{b}$ & Medium & $9.85 \pm 1.84^{\mathrm{b}}$ \\
\hline P30 & 30.88 & 27.94 & 41.17 & $75 \pm 2.21^{\mathrm{C}}$ & High & $10.90 \pm 1.52^{\mathrm{c}}$ \\
\hline
\end{tabular}

Note: NP: Control group (normal), P0: Perimenopause induction with VCD injection; P15: Perimenopause mice followed by S. androgynus leaf extract treatment at dose $15 \mathrm{mg} / \mathrm{kg} \mathrm{BW}$; P30: Perimenopause mice followed by S. androgynus leaf extract treatment at dose $30 \mathrm{mg} / \mathrm{kg}$ BW. Different superscript showed significant differences among treatment group $(\mathrm{p}<0.01)$ on LSD test.

Table 3: Endometrial thickness of premenopausal female mice after treatment of $S$. androgynus leaves water extract.

\begin{tabular}{cc}
\hline Treatment & Mean \pm STDV $(\mu \mathrm{m})$ \\
\hline N & $362.82 \pm 38.87^{\mathrm{b}}$ \\
P0 & $268.83 \pm 14.87^{\mathrm{a}}$ \\
P15 & $313.34 \pm 21.72^{\mathrm{ab}}$ \\
P30 & $342.40 \pm 23.58^{\mathrm{b}}$ \\
\hline
\end{tabular}

Note: Different superscript showed significant differences among treatment group $(\mathrm{p}<0.01)$ on LSD Test
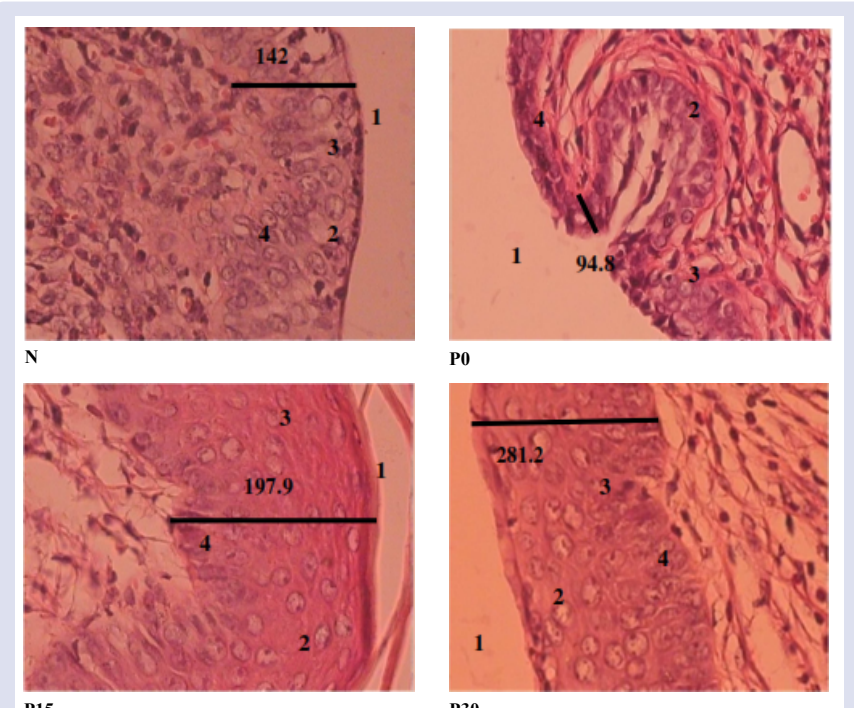

P0

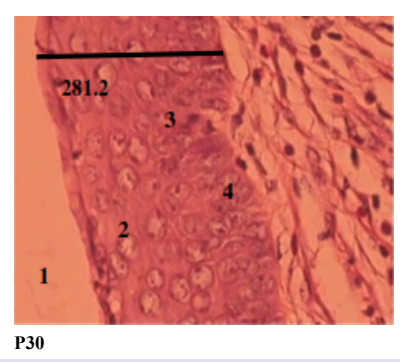

Figure 2: Vaginal epithelium thickness in perimenopause mice after $S$. androgynus leaf extract treatment for 30 days (400x magnification). Note: $\mathrm{N}$ : Control group; P0: Mice with VCD induction; P15: Perimenopause mice treated with S. androgynus Leaf extract at dose $15 \mathrm{mg} / \mathrm{kg} \mathrm{BW;} \mathrm{P30:}$ Perimenopause mice treated with $S$. androgynus leaf extract at dose 30 $\mathrm{mg} / \mathrm{kg}$ BW. (Note: 1. Lumen, 2. Superficial cells, 3. Intermediate cells, 4. Parabasal cells; $400 x$ of magnification).

\section{DISCUSSION}

Perimenopause or menopausal transition represents of reproductive to non-reproductive life. VCD intra peritoneal injection doses of $160 \mathrm{mg} / \mathrm{kg}$ BW 5 times for 14 days in mice could extend the estrous phase especially diestrus phase (Table 1). The estrus phase gap is one of the characteristics of perimenopause, especially elongation of the diestrus phase. One of the signs of perimenopause is the existence of irregular menstrual cycles. In the later stages of perimenopause, the cycles may become much longer. ${ }^{12}$ VCD induction causes the failure of ovarium that characterized by the longest estrous cycle with the duration of diestrus phase exceeds the normal phase ( $>120$ hours) and continuously. ${ }^{13}$ These results demonstrate that the VCD-treated mice can serve as an appropriate model to mimic hormonal changes during the perimenopausal transition in women.
The diestrus phase duration in perimenopause female mice was examined by proestrus, estrus, and metestrus phase observation (Figure 1). In proestrus phase, the estrogen level was increased and blood stream was increased intensively in vaginal mucosa tract. Thus, epithelial cells of reproductive tract were proliferating. The proliferation of epithelial cells in endometrium, vagina, and ductus gland were indirectly affected by paracrine factor of stroma cells resulted in estrogen induction. ${ }^{14}$ Estrus phase have more estrogen level and blood supply to vagina was increased. The rising levels of estrogen rapidly induce the cornification of vaginal epithelial cells. Metestrus phase is characterized by the decreasing of estrogen and vascularization. Thus, vaginal epithelial cells is released and leucocyte is organized. ${ }^{15}$

As indicated in Table 1, this study revealed that the percentage of parabasal cells mostly found at P0 (41.84\%). It is indicated that VCD induction causes vaginal epithelial not differentiation. The percentage of superficial cells at P15 group was $40.17 \%$, while P30 group was $41.17 \%$. This condition indicated that vaginal epithelial cell has been differentiated. Vaginal epithelium thickness and maturation is depending on estrogen level (or estrogenic activity). The large number of superficial cells indicates a high estrogenic activity, while the large number of parabasal cells indicates a low estrogenic activity in the body. Deficiency estrogenic activity causes decreasing of epithelial proliferation and epithelial maturation. This may be due to a decline in all layers except basal cells layer. ${ }^{16}$
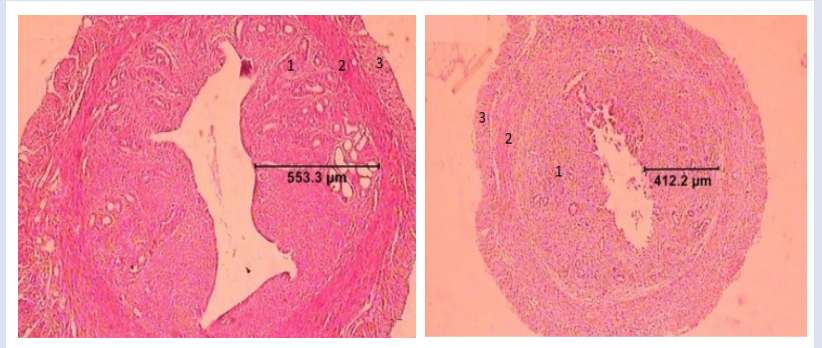
P0

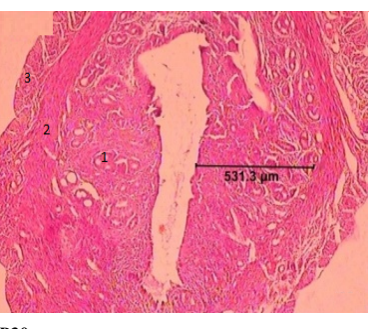

P15 P30

Figure 3: Endometrial thickness in perimenopause mice after $\mathrm{S}$. androgynus leaf extract treatment for 30 days (40x magnification). Note: Note: N: Control group; P0: Mice with VCD induction; P15: Perimenopause mice treated with $S$. androgynus leaf extract at dose 15 $\mathrm{mg} / \mathrm{kg}$ BW; P30: Perimenopause mice treated with $S$. androgynus leaf extract at dose $30 \mathrm{mg} / \mathrm{kg}$ BW. (Note: 1. Endometrium 2. Myometrium 3. Perimetrium) 
This study also found that vaginal epithelial proliferation in all group was significantly different. P0 group have a low thickness and maturation index of vaginal epithelial cells compared to P15 and P30 group (Table 1). A low estrogen level by VCD induction will cause ovarium faillur then caused dysregulation of vaginal epithelium maturation and proliferation. Menopause mice condition with VCD induction caused accelerated ovarian follicle atresia through the increased apoptosis protein may cause fallen ovarian ability to produce estrogen and boost uterine growth. Decreasing the estrogen concentration within blood may affect the endometrium thickness and uterine glands. ${ }^{17}$

Histological analysis showed that parabasal cells, a few of intermediate and superficial cells are mostly found in vaginal epithelial layer at VCD group. This might be caused by declining all layers except basal cell ${ }^{16}$ and epithelial layer depletion. P15 and P30 group were administered $S$. androgynus leaves extract with various doses also has differences of vaginal thickness and proliferation. This study showed that $S$. androgynus leaves extract administered to female mice with premenopause condition was significantly different on thickness and maturation index of vaginal epithelial cells $(\mathrm{p}<0.01)$ (Table 1, Figure 2). It was in line with Raden finding ${ }^{17}$ given extracts of Centella asiatica on day 22 post-ovariectomy with a dose of $30 \mathrm{mg}, 60 \mathrm{mg}, 120 \mathrm{mg} / \mathrm{kg}$ BW/ day for 40 days orally, that showed an increase in epithelial proliferation, maturation of the vaginal wall significantly. Bedell et al..$^{18}$ found the pros and cons of plant estrogens for menopause certain phytoestrogen shown decrease vaginal atrophy. Epithelial cells mitosis enhances the proliferation of epithelial cells. It was indicated by increasing of epithelial cells proliferation and thickness. ${ }^{15}$ The vaginal epithelial thickness at P30 group $(10.90 \pm 1.52 \mu \mathrm{m})$ thicker than P15 group $(9.85$ $\pm 1.84 \mu \mathrm{m})$. Thus, the effective dose for enhance the vaginal epithelial cells proliferation was $30 \mathrm{mg} / \mathrm{kg}$ body weight caused high estrogenic effect (Table 2, Figure 2).

This research also found that $\mathrm{P} 15$ and $\mathrm{P} 30$ endometrium are thicker than P0 (Table 3, Figure 3). This condition may be fixed by applying phytoestrogen compound. Isoflavones content in S. androgynus leaf extract, as suggested in research result performed by Wijono, ${ }^{6}$ showed that this extract is able to provide the estrogenic effect and improve the endometrial thickness. Sirotkin and Harrath ${ }^{19}$ also explain about the mechanism of this process, which is phytoestrogen compound will bind itself with hormone receptors available on cell target, thus it will change hormone receptor conformation. This conformation change leads into an active phytoestrogen receptor thus it will be able to perform site binding on DNA chain, especially on the acceptor side. The interaction between phytoestrogen receptor and DNA acceptor side cause the increased gene expression. This gene expression then being catalysed by RNA polymerase enzyme which may lead into the increased mRNA. On the other hand, tRNA synthesis will also increase, and at last, cell material synthesis becomes much higher which may support cell proliferation activity. ${ }^{19}$

S. androgynus leaf extract have direct and indirect effect on reproduction system which associated with estrogen receptors. $\alpha$-Estrogen receptor was expression in uterus and vagina. ${ }^{20}$ Indirect effect, S. androgynus leaf have large phytochemicals compound used for traditional medicine. S. androgynus leaf contains 7 active compounds which is potential to enhance steroid hormones (progesterone, estradiol, testosterone, and glucocorticoid) and eicosanoid compound (prostaglandin, prostacyclin, thromboxane, lipoxin, leukotriene). One of the compounds is androstane-7-one,3-ethyl-3-hydroxy-5 alpha $\left(\mathrm{C}_{21} \mathrm{H}_{24} \mathrm{O}_{2}\right)$ which is exist as precursor or intermediate-step in steroid hormone synthesis. ${ }^{21}$

Direct effect, estrogen receptor $\alpha$ is fully agonist which isoflavonoid mechanism by estrogen receptor, directly affected to the gene transcription..$^{22}$ In menopause condition, isoflavonoid is estrogenic by which they replaced estrogen endogenous to bind with estrogen receptor. ${ }^{23} S$. androgynus leaves that contain isoflavonoid are strongly estrogenic to vaginal epithelial cell in perimenopause female mice by affecting their proliferation. ${ }^{20}$ Isoflavonoids are referred to as phytoestrogens with $\mathrm{A}-\mathrm{C}$ ring which almost similar to $\mathrm{A}-\mathrm{B}$ ring in estrogen and similar to hydroxyl group at position 5 . The position of this ring could play a role in the promoting of estrogen activities.

\section{CONCLUSION}

Administration of $S$. androgynus leaf extract at dose $30 \mathrm{mg} / \mathrm{kg} \mathrm{BW}$ increased the estrogenic effect to high condition. Administration of the extract led to a statistically significant decrease in the duration of the diestrus phase, a statistically significant increase in the thickness of the vaginal epithelium, and a statistically significant increase in the maturation index. Apparently, the S. androgynus leaf possessed meaningful estrogenic activity and may be useful for treating perimenopausal vaginal and endometrial atrophy

\section{ACKNOWLEDGEMENT}

I would like to thank Dean of Faculty of Science and Technology, State Islamic University of Maulana Malik Ibrahim for funding this research through Strengthening Institution Program of DIPA.

\section{CONFLICT OF INTERESTS}

We declare that we have no conflict of interest.

\section{CONTRIBUTION OF AUTHORS}

We declare that this work was done by Retno Susilowati, Lailatul Khoiriyah, Exma Mutatal Hikmah and all liabilities pertaining to claims relating to the contents of this article will be borne by the authors. Retno Susilowati performed the study design and drafting the manuscript, Lailatul Khoiriyah performed the data analysis and Exma Mutatal Hikmah performed the final approval of the manuscript.

\section{REFERENCES}

1. Lima SM, Yamada SS, Reis BF, Postigo S, Galvão da Silva MA, Aoki T. Effective treatment of vaginal atrophy with isoflavone vaginal gel. Maturitas. 2013;74(3):252-8

2. Abedi P, Najafian M, Yaralizadeh M, Namjoyan F. Effect of fennel vaginal cream on sexual function in postmenopausal women: A double blind randomized controlled trial. J Med Life. 2018;11(1):24-8.

3. Lindahl $\mathrm{SH}$. Reviewing the options for local estrogen treatment of vaginal atrophy. Int J Womens Health. 2014;6:307-12.

4. Kaban I, Kaban A, Tunca AF, Aka N, Kavak H, Akar F. Effect of pomegranate extract on vagina, skeleton metabolic and endocrine profiles in an ovariectomized rat model. J Obstet Gynaecol Res. 2018;44(6):1087-91.

5. Tristan JK, Tetyana S, Alice ML, Bruce KF, Ke-Ming C, Peter RH, et al. Potential effects of phytoestrogen genistein in modulating acute methotrexate chemotherapy-induced Osteoclastogenesis and bone damage in rats. Int J Mol Sci. 2015;16(8):18293-311.

6. Wijono S. Isolasi Dan Identifikasi Asam Fenolat Pada Daun Katu (Sauropus androgynus (L.) Merr.). Makara Kesehatan. 2004;8(1):35.

7. Hayati A, Arumingtyas EL, Indriyani S, Hakim L. Local knowledge of Katuk (Sauropus androgynus (L.) Merr) in East Java, Indonesia. Int J Curr Pharm Rev Res. 2016;7:210-5.

8. Srinivas S, Maiti S, Jothilakshmi P. Management of proliferative endometrium on biopsy in post-menopausal women. J Gynecol Obstet. 2016;4(6):38-43.

9. Van Kempen TA, Milner TA, Waters EM. Accelerated ovarian failure: A novel, chemically-induced animal model of menopause. Brain Res. 2011;1379:176-87.

10. Srinivasan MR, Sabarinathan A, Geetha A, Shalini K, Sowmiya M. A comparative study on staining techniques for vaginal exfoliative cytology of rat. $\mathrm{J}$ of Pharmacol \& Clin Res. 2017;3(3):1-4

11. Wilson DR. How Perimenopause can affect your periods and what you can do 2017 [cited 2017 Dec 14]. Available from: https://www.healthline.com/health/ menopause/perimenopause-periods.

12. Craig Z, Marion S, Funk J, Boussein M, Hoyer P. Retaining residual ovarian tissue following ovarian failure has limited influence on bone loss in aged mice. J Osteoporos. 2010;2010:1-6. 
13. Sampey BP, Lewisa TD, Barbiera CS, Makowskib L, Kaufmana DG. Genistein effects on stromal cells determines epithelial proliferation in endometrial cocultures. Exp Mol Pathol. 2011;90(3):257-63.

14. Cora M, Kooistra L, Travlos G. Vaginal cytology of the laboratory rat and mouse: review and criteria for the staging of the estrous cycle using stained vaginal smears. Toxicol Pathol. 2015;43:776-93.

15. Baziad A. Menopause dan Andropause. Jakarta:Yayasan Bina Pustaka Sarwono Prawirohardjo:2003.pp:56.

16. Witmer GW, Raymond-Whish S, Moulton RS, Pyzyna BR, Calloway EM, Dyer $\mathrm{CA}$, et al. Compromised fertility in free feeding of wild caught Norway Rats (Rattus norvegicus) with a liquid bait containing 4-Vinylcyclohexene diepoxide and triptolide. J Zoo Wildl Med. 2017;48(1):80-90.

17. Raden A. Effect of Pegagan (Centella asiatica) extract in ovariectomized wistarstrain rattus norvegicus on epithelial proliferation of vaginal wall. Jurnal IImiah Kedokteran Hewan. 2011;4(1):71-6.

18. Bedell S, Nachtigall M, Naftolin F. The pros and cons of plant estrogens for menopause. J Steroid Biochem Mol Biol. 2014;139:225-36.
19. Sirotkin AV, Harrath AH. Phytoestrogens and their effects. Eur J Pharmacol. 2014;741:230-6.

20. Bryś M, Szyłło K, Romanowicz-Makowska H, Dobrowolski Z, Masłowska I, Krajewska W. Expression of estrogen and progesterone receptor genes in endometrium, myometrium and vagina of postmenopausal women treated with estriol. Sao Paulo Med J. 2009;127:128-33.

21. Suprayogi A. Studies on the biological effects of Sauropus androgynus (L.) Merr.: Effects on milk production and the possibilities of induced pulmonary disorder in lactating sheep. Germany: Cuvillier Verlag Göttingen;2000.pp:173.

22. Winuthayanona W, Hewitta SC, Orvisb GD, Behringerc RR, Koracha KS. Uterine epithelial estrogen receptor $\alpha$ is dispensable for proliferation but essentia for complete biological and biochemical responses. Proc Natl Acad Sci USA 2010;107:19272-7.

23. Darmadi DT, Nurdiana, Norahmawati E. The effect of blackeyed peas on osteoblast and osteoclast of rat with ovarectomy. Jurnal Kedokteran Brawijaya. 2011;26:151-5.

\section{GRAPHICAL ABSTRACT}

\section{Katuk (Sauropus androgynus)}

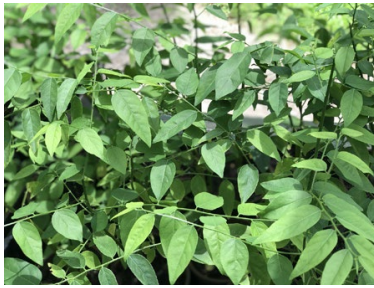

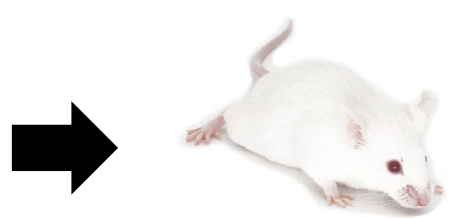

Perimenopausal mice

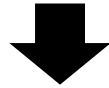

Vaginal Epithelium and Endometrium atrophy
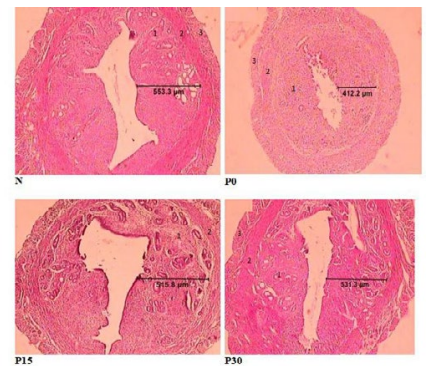
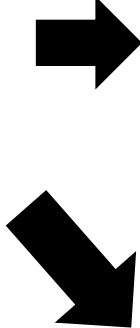

Duration of diestrus phase

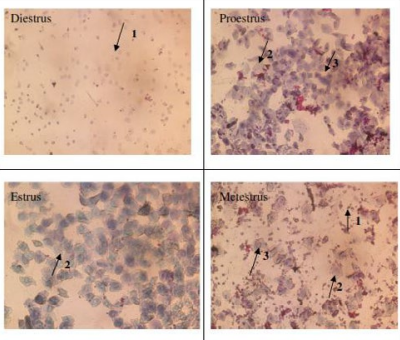

Maturation Index (MI)
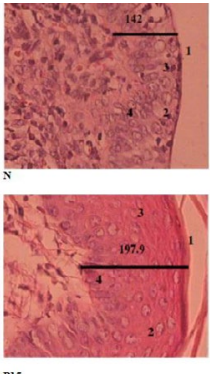
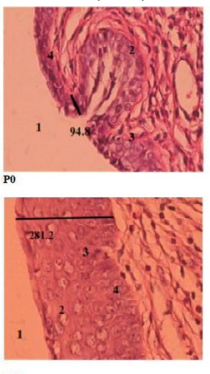

\section{ABOUT AUTHORS}



Retno Susilowati received her doctoral degree at Brawijaya University, Malang, Indonesia (2011). She is currently a lecturer at Department of Biology, Faculty of Science and Technology, State Islamic University of Maulana Malik Ibrahim Malang, Malang, Indonesia. Her research interest is biomedical field and animal physiology.

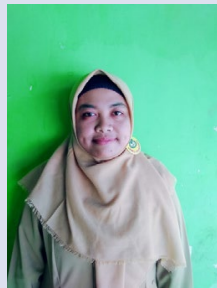

Lailatul Khoiriyah received her bachelor degree at Department of Biology, Faculty of Science and Technology, State Islamic University of Maulana Malik Ibrahim Malang, Malang, Indonesia. Her current research is about animal reproduction. 


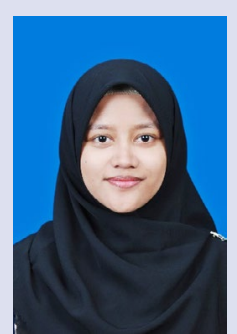

Exma Mutatal Hikmah received her master degree at Airlangga University (2018). Her research interest includes basic medical science of physiology.

Cite this article: Susilowati R, Khoiriyah L, Hikmah EM. Estrogenic Effect of the Leaves from Katuk (Sauropus androgynus L. Merr) on Vaginal and Endometrial Atrophy in Perimenopausal Mice. Pharmacog J. 2020;12(2):240-5. 